\title{
Understanding the Post-Colonial Literature in the Novels of Amitav Ghosh and Salman Rushdie- A Postcolonial Comparative Study
}

\author{
Dr. Venkateswarlu Yesapogu, M.A., M.Phil, PhD. Head \\ Dept of English, Principal FAC in V.V. \& M Govt Aided Degree College \\ Ongole, Prakasam D.T., A.P. India \\ Smt. Manjula Kandula, M.A., M.Ed, M.Phil \\ Principal Priyanka College of Education, Chekoorapadu \\ Cheerala Road, Ongole, Prakasam D.T. A.P. India
}

\begin{abstract}
In the contemporary Indian Literary scenario, Salman Rushdie and Amitav Ghosh are the only writer who reflects the truth of Indian reality. They bear numerous responsibilities in the world of literature. They execute with admirable aplomb as an anthropologists, sociologists, novelists, essayists, travel writers, and who slip into global responsibility for establishing peace as the ambassadors. They have excelled the global literary standards set by the post colonial and post modern writers like, Vikram Seth, Vikram Chandra, Sashi Tharoor, Arundhati Roy etc.They have become the colossal central socio literary figure with a substantial body of work drawing the global attention. They have become the only negotiators to mediate the core social and cultural problems of India and other colonized nations. All their major works have enjoyed immense academic attention across the globe and which have invited and produced a great amount of literary criticism. They have created a wide readership and a strong critical endorsement that reflect the attention of serious academicians and scholars. All the post colonial and post modern predicaments are wrestled to demonstrate a high level of self consciousness which continues interrogate the social, philosophical, cultural issues of the world in all its relevance and freshness. Their works have initiated the emergence of critique of nationalism and universalism. Their intellectual insights, conceptual, theoretical and textual experiments have engaged and interpreted the complex colonial and post colonial situations. They have established a peculiar paradox of reading and appreciation eloquently responding to the post colonial and post modern issues of evolution and transformation of the world. Making their debut with Midnight's Children (1980) and The Circle of Reason in 1986, which have produced the ground breaking novels till today with that interrogate the history of humanity with discursive discourses.

However their non fictional writings are equally challenging and stimulating offering philosophical and cultural elucidation on different themes such as fundamentalism, history of the novel, Egyptian culture and literature. Despite this vast amount of creative and critical output surprisingly there is a small amount of critical reception. But their works have become the most favoured areas of scholarly exploration for many of the young scholars and academicians. These explorations have become part of unpublished research that focused exclusively on the post-colonial aspects in relevance of both Salman Rushdie and Amitav Ghosh to the contemporary times.
\end{abstract}

Keywords: Colonized nation, post-colonialism, history, fundamentalism, literature, nationalism.

\section{INTRODUCTION}

The first of the new novelists to arrive was Salman Rushdie whose Midnight's Children (1980) heralded a new era in the history of Indian English fiction. His main assets are a vaunting imagination, which often makes the bizarre its business, a carnivalesque sense of the comic, and an irrepressible love of word play. When these powers are under perfect artistic control, and are geared to meaningful central concerns. Rushdie's Word play descends to the level of compulsive jesting. He seems to fall back on puerile puns, Juvenile jokes and worn out witticisms. It is his hyperactive imagination that must have drawn Rushdie to surrealism, and its modern cousin, Magic Realism. He strategically carves affinities with the strong oral traditions and narrative pattern of the Third World Societies. Rushdie's another novel Satanic Verses (1988) brought him considerable notoriety, as devout Muslims found it blasphemous. 
Post-colonial studies have been with us for the last many years and at present they are foremost in any curriculum of Literature in English. Perhaps the most interesting thing is that the current literature in English is heavily relying on the literature coming from post-colonial topics and post-colonial writers living in British ex-colonies or living in Britain or the United States but were born and bred in colonized countries. Writers as diverse as Chinua Achebe and Wole Soyinka from Nigeria, Salman Rushdie and Amitav Ghosh from India, Derek Walcott from the Caribbean, Seamus Heaney from Ireland, Margaret Atwood and Michael Ondaatje from Canada, Peter Carey and Patrick White from Australia, and J. M. Coetzee and Nadine Gordimer from South Africa have been prominent when major literary awards such as the Booker Prize or the Nobel Prize have been announced.

The novels of Amitav Ghosh and Salman Rushdie are the true representative of postcolonial fiction. They embodie in their own life and through their writings the riddle of the postcolonial authors, writing within the traditions of Indo-English literature while simultaneously appealing to the conventions and tastes worldwide, especially a Western audience. In their novels, Rushdie and Ghosh deal with various National and International themes, but their primary focus is their motherland and its subcontinents. Themes such as migration, exile, diaspora, nationalism, multiculturalism, dualism, post-modernism and postcolonialism etc which are appear in their novels from the very first page. Moreover, their writings have become the focus of a certain kind of struggle for cultural identity in Britain and other Western states. They are the spokesperson for the people of the subcontinent who are living in their migrated countries.

All the novels of both Amitav Ghosh and Salman Rushdie are quintessential postcolonial novels. Post-colonial criticism has become academically compelling criticism. Post-colonial theory explores the textual criticism of post-colonial literatures. Frantz Fanon's Black Skin White masks (1952) and Wretched of the Earth (1967) and Edward said's Orientalism (1978) and Culture \& Imperialism (1993) are considered to be the promulgators of Post-colonial criticism. These seminal works have strongly recommended the reclamation of the past of colonized nations only to subvert the hegemony of the colonial nations. Bill Ashcroft, Gareth Griffith \& Helen Tiffin's The Empire Writes Back (1989) with a broader cultural circumscription of all the colonized nations provided a strong base for post-colonial criticism. This is further continued and consolidated by Gayathri Spivak Chakravarthy In Other Worlds: Essays_in cultural Politics (1988), Homi K.Babha's Nation and Narration (1990) and Location of Culture (1994). These works have interrogated the identities of colonialism. The concocted colonial identities of Nation, Nationality, and National representations are interrogated and the male centered perspectives are demolished. All these novels that examined for this article engage in the critical negotiation of past history by Amitav Ghosh and Salman Rushdie. The presentation of past history is with ambiguity. The ambiguous nature of past history has revealed the dichotomy of the past history as glorious and inglorious which interface fiction. The usable past becomes the glorious past and the unusable past becomes the inglorious past.

All these novels need to be examined in understanding the dichotomy of 'Colonialism'. It needs to be examined in relaxation to 'internal colonialism' and external colonialism. India is a country, which suffered from 'Internal colonialism' since the beginning of its civilization. It continues to suffer from 'Internal colonialism' even after the demise of colonial period. Women in India are the victims of 'Internal colonialism' as well as the external colonialism. The victimization of women in 'Internal colonialism' went on unabatedly in silent acceptance. Post-colonial criticism has also revealed and questioned the patriarchal mechanism in victimizing women by creating the passive images of contemporary issues. The protagonists in all these novels of Ghosh and Rushdie are the victims of internal colonialism.

Carrying the mantle of the passive roles of women, the protagonists tried to liberate themselves. It is only with post-Colonial criticism the issues of confrontation dealt by these works can be deciphered. The protagonists in all these novels in the process of liberating and defining themselves tried to establish alternative roles. For instance, the protagonist in "Sea Of Poppies" (2008) is confronted by the horrifying future carrying the burden of innocent past life in India. There is a juxtaposition of the life spent in India and the life being lived in the northern Bihar. In the process of living in northern Bihar, she obliterates the conventional images of motherhood. 'Sea of Poppies' of Ghosh perfectly presents the juxtaposition between the pre-colonial India and post-colonial India. The very transformation of the protagonist from a submissive domestic life is rendered in all its appreciation. This obviously presents the radicalization in the very construction of social identities and positions. 
The social maturation in the character provides a space in which the pre-colonial constructions of Nation and Nationality are interrogated.

In the novel The Glass Palace along with the discussion of colonial rulers and their subjects Queen Supayalath carries on a discourse that unruly depicts 'cruel politics'. If the Indian princes constitute the other in the power game between the British and themselves, it is Queen Supayalath who is symbolic of woman as the other in human relationships. As living in Burma Jaya is brought into light by the skills of her research. The journey of Jaya's research from her childhood to maturity is full of enriching experiences.

Post-colonial criticism has initiated significant changes in the discourse of nationalism of colonized countries. It offered genuine criticism of the evolution of the feeling on Nationalism. It has projected the idea that Nationalism has emerged to check the growth of capitalism and Industrialization. Ernest Gellner in Nations and Nationalism (1983) observed that Nations are not inscribed into the nature of things. Nations are like planned things. They are like constructed buildings. The very idea of the nation is considered to be a myth. Benedict Anderson in Imagined Communities: Reflections on the Origins and_Spread of Nationalism (1983) argues that nations are imagined political communities. The essential symbols like national flag, national bird, national animal, national anthem that stood for the significance of nationalism are all prepared cultural artifacts by the so-called pre independent national leaders.

Post-colonial criticism has also revealed the very cultural strategy involved in identifying the land of the nation with the body of the women. This is intentionally schemed to incite the sentiments of the common people. The occupation of their land is projected as the molestation on the dignity of their woman. The colonial occupation is interpreted on these lines only to invite the participation of the common people in the so-called struggle for independence. It is pertinent to observe that in the larger struggle for Independence the very crucial aspect of the Independence of women is excluded. It is from this perspective Partha Chatterjee in his influential book Nationalist thought and colonial world (1986) considers nationalism as a derivative discourse. He considers that idea of Nationalism is in complicit with the elite sections of the society. Post-colonial criticism has also revealed how the nature and subjectivity of women's life is exploited by the national leaders in their struggle for freedom. Particularly Mahatma Gandhi is understood to have exploited the subjectivity of Indian womanhood in his methods of staging hunger strike, non-cooperation and non-violent demonstrations. Gandhi has exactly employed the nature and psyche of Indian womanhood. Post-colonial criticism has revealed the ways in which the subjectivity of Indian womanhood is exploited like Deeti in Sea of Poppies (2008) only to further undermine the social positions of Indian women and Gandhi is no exception in the scheme of Indian patriarchy.

The women protagonists in these novels are the representatives of post-colonial critique of Indian society. Deeti, Munia, and Paulette in Sea of Poppies and Dolly and Uma in The Glass Palace are the apt representatives of post-colonial critical spirit. The life related to the mother and daughter weaves between the pre-independent and post Independent India presenting the glimpses of usable past and unusable past. The holocaust during the times of partitions strongly signifies the inglorious past.

The post-independence situation which Jaya constructs her life to the level of challenging the intellectual hegemony of researcher is nothing but the obliteration of all the imposed social roles. The self-affirmation that Deeti exhibits reveals the true colour of colonial intrigues that multiplied gender inequality and discrimination.

Ghosh's The Hungry Tide is also a quintessential post-colonial novel. Moreover, the theme of Sea of Poppies perfectly suits the post-colonial propositions as it presents the position of Indian women in pre-Independent and post-Independent situation of India. The colonial and the social displacement of Indian nobility and the kingly class in Dancing in Cambodia, at Large in Burma is well crafted within the post-colonial critical framework. One of the protagonists in The Glass Palace Jaya displays the required wisdom to understand British colonialism better than the other male characters. In the male dominated culture of The Hungry Tide and Sea of Poppies Piya and Deeti, win the legitimacy to inherit the rule purely on their own. In this process, they overcome the conventional hurdles of Kabutri, the daughter of Deeti and Tutel, son of Fokir considered as the natural heir to Fokir and heiress to Deeti. Princess Soumphady becomes the true representative of Indian Culture by ably implementing the dancing lessons and principles of ruling the nation after the King Sisowath. 
Enacting the conventional role of wife and as well as mother, Deeti upholds the dignity of the Indian culture by disallowing the cunningness, cruelty and perverted intrigues of Chandan Singh who is a colonial representative. She also realizes that the ultimate legitimacy to rule the nation rests with the 'people' and obliterates the patriarchal authority. The way Deeti registers protagonism is the way, which unravels the intrigues of conventional images and symbols meant for manufacturing the socalled pseudo nationalism. Post-colonial criticism of the nationalism of colonized nations finds sagacity in the very interpretation of Amitav Ghosh's Sea of Poppies.

Colonialism had condemned millions to a life of subservience and dispossession. At this juncture, the anti-colonial nationalisms promised a new dawn of independence and political self-determination for colonized people. In the twentieth Century, the myth of nation has proved highly potent and productive during several struggles against colonial rule. Under the development of created constructed myths, the nation became highly mobilized as a powerful symbol, which anti-colonial movements used to organize against colonial rule.

The colonial rule has dismantled the political structures of many nations and the worst hits were the countries of the South Asian region. Many countries had become the British colonies. In the South Asian regions, it was India, Burma and Malaysia that suffered from the colonial oppression. These countries are known for their rich cultural heritage, richest natural resources and abundant wealth.

The British intrusion into these lands in the name of business exemplified the strategy of colonialism. However, the intrusion into the serene lands had no effect on the part of the commoner. In fact, the commoner thought that the colonial rule came as a liberating agency from that of the monarchical rule, which they are facing. Especially in Burma, the commoner had developed an aversion towards their King Thebaw and the Queen Supayalat. The opening chapters of The Glass_Palace reveal the aversion of the Burmese crowd towards their superior authority. "Through all the years of the Queen's reign the townsfolk had hated her for her cruelty, feared her for her ruthlessness and courage" (34). The looting of the King's palace by the Burmese Public clearly shows their aversion. When the British had seized Thebaw from power, it was the public who has to lend the support through difficult phase of time. Instead of that, they turned against him and they indulged in looting their own King's Palace. The King has failed as a good ruler. That was the reason why they considered the British as the liberating agency. It is here the question of state comes into light. In the countries, which are governed by the state, people develop a sense of looking after the well-being of each and every individual. This tendency provides source of revenue for its people and sets the standards of living. By doing so, the state gains a perfect control over its people and the social hierarchy runs with perfection. But if the state fails in providing livelihood and other necessities for its people, it loses control over them and hierarchy gets dissolved.

The British intrusion into Burma had changed everything. Thebaw lost his power and so the Queen. Their own people had looted their palace. It was a huge humiliation for the royal couple. They never noticed the growing unrest in the public of their rule. When the British came into the land the crowd seized the opportunity to sneak into the palace. Until the British arrival, no commoner in the country had dared to enter into the palace. They knew that it would result in summary execution. But now everything has changed. The King and the Queen were thrown out of power. The Queen's reaction when she saw the mob inside their palace shows her impotence.

The King and the Queen along with trusted servants were shabbily been discarded from the country to a remote coastal village in India. No one in the country felt sorry for their eviction from the country. It was the colonial rulers ploy in exiling the King's family from their own land in order to erase them completely from the public memories. Earlier, the Indian Mughal King, Bahadur Shah Zafar too was exiled in the same manner. The colonial rulers exiled him to Rangoon from India.

The colonial rule has a huge affect on the members of the elite group in Burma as well as in India. Prior to the British occupation, they had a strong food hold in the country. But now they have lost their grip on the soil. In order to raise their voice against the colonial rule their number is limited and they needed the support of all the people. Until then, they never considered the other people and the social hierarchy had created a great abyss between them and the subaltern people. "Many once colonized nations have struggled with the internal differences that threaten the production of national unity" (McLeod: 2000). The term 'Subaltern' is used to signify the many different people who did not comprise the colonial elite. The colonial elite includes, the lesser rural gentry, impoverished landlords, rich peasants and the upper middle class peasants. 
Moreover, the past half-century, postcolonial literatures and postcolonial studies have gained the attention of more and more readers and scholars throughout the world Writers as diverse as Chinua Achebe and Wole Soyinka from Nigeria, Salman Rushdie and Amitav Ghosh from India, Derek Walcott from the Caribbean, Seamus Heaney from Ireland, Margaret Atwood and Michael Ondaatje from Canada, Peter Carey and Patrick White from Australia, and J. M. Coetzee and Nadine Gordimer from South Africa have been prominent when major literary awards such as the Booker Prize or the Nobel Prize have been announced, and their works now appear on numerous School and University for research work and syllabuses. Concurrently, their writing has provided the nourishment for a variety of postcolonial theories concerning the nature of such works, approaches to reading them, and their significance for reading and understanding other literary, philosophical and historical works. Indeed, the production of introductions to postcolonial theory has become a major industry. However, this paper looks for to spotlight on the literary texts rather than the theories, and to give a general sense of the issues and choices which inform the writing and reading of those texts, about the ways in which these issues have, involved the questions of genre, form and language, as well as social and political concerns changed over the decades. Although this paper will concentrate on literature written in English by Amitav Ghosh and Ahmed Salman Rushdie', Bombay-born member of the colonized groups, it is important to bear in mind the differing histories of each former colony and the impact of those differing histories. Four names appear again and again as thinkers who have shaped postcolonial theory: Frantz Fanon, Edward Said, Gayatri Chakravorty Spivak and Homi Bhabha, critics and theorist whose name frequently recurs in discussions of postcolonial literary and cultural studies, representing on psychoanalytical theory with particular reference to Sigmund Freud and Lacan, Bhabha has elaborated the key concepts of mimicry and Hybridity. Whereas, 'Fanon and Said', have analyzed the oppositions set up in colonialist and anti colonialist societies, Bhabha has sought to demonstrate that their discourses contain ambivalences and ambiguities. They both of them argue that the mimicry of colonizers by colonized subjects can be a form of subversion, since it makes unstable the insistence on difference which forms the basis of colonialist and nationalist ideologies. Like 'Said and Spivak', Bhabha celebrates the 'Hybridity' of postcolonial cultures, seeing their embrace of European as well as indigenous traditions as a positive advantage which allows their writers and critics to understand and critique the West as both insiders and outsiders.

But it is important not to assume that theory relevant to postcolonial literary analysis is confined to those two or three names which have become so dominant in the past two decades. Post-colonial studies have been with us for the last many years and perhaps the most interesting thing is that the current literature in English is heavily relying on the literature coming from post-colonial topics and post-colonial writers Amitav ghosh and Salman Rushdie who have been living in British ex-colonies or living in Britain or in the United States but were born and bred in colonized countries. This paper will not touch on British authors and novels with postcolonial themes, such as Marina Warner and Zadie Smith Coetzee, Gordimer, Melville, Naipaul, Melville, Phillips, all postcolonial writers from South Africa, India and the Caribbean. Its aim is to artifact the contemporary novels of both writers in English published from 1970-2008 and afterwards and written by postcolonials themes well. Needless to say, it will neither embrace all the novels published nor most of them. This paper tries to give an abstract of some novels written by the best post-colonial writers of Amitav Ghosh and Salman Rushdie, with the analytical themes, with special reference to the diaspora and transculturation, And where India, other sub- continent and continent, are represented in the context of their literary, stateof-art- various genres like history, mythology, religion, oral tradition etc., with piercing social and political annotations. And the novels of Amitav Ghosh and Salman Rushdie who in their works are relic of our rational, irrational times, significantly, contribute to diverse interpretations that are characteristic of the postmodern environment of world literary writings.

For, this purpose, I choose the novels of both Ghosh and Rushdie The Glass Palace and 'Mid Night Children' have written about India's strive for Independence from British colonialism, and 'Two years, eight months, and twenty- eight nights,' published in 2015- is contemplation on the age of unreason, we live in, and notably shaped the course of Indian writings in English. 'Ahmed Salman Rushdie', Bombay-born and England-bred, has emerged during the last several decades as an enormously significant voice in the field of postcolonial and world literary studies.

Whereas Salman Rushdie just like Ghosh, is the author of eleven previous novels, prior to new one published in 2015, one collection of short stories, four works of non-fiction and co-editor of two 
anthologies. Rushdie's literary career started with his first novel, Grimus (1975), which was a poor seller. Since the publication of his second novel, 'Midnight's Children' in 1981, Rushdie's works have made a remarkable mark on the meadow, influencing countless other Indian and migrant writers and sparking an extensive body of critical and theoretical writings based on his ideas. The 'Shame' and "Satanic Verses' (1988) made him one of the best contemporary novelists in the world. His masterful yet world- shattering novels playfully mix magical realism with piercing social and political annotations. In the 40 years of his writings career, Salman Rushdie has been the subject of great attention and debate, receiving both adoring praise and condescending reviews. Midnight's Children won for him the Booker of Bookers prize and it was selected as The Best of Bookers. Rushdie was knighted in 2007 for services to literature.

His first novel Grimus (1975) was a science fiction and it did not draw much attention of the critics and readers alike His second novel, Midnight's Children, was published in 1981. It is a fantastic allegory of the developments in contemporary India and it won him several awards including the Booker prize.His third novel, Shame, appeared in 1983 and it deals with the political situation in Pakistan. The Satanic verses, were published in 1988. The book has caused violent controversy in the Muslim world because part of it is an obvious allegory on Muhammad's life and the birth of the Koran but it indicates that Mahound (the allegory on Muhammad) might not be as pure a person and it also ridicules the Koran at some places. The book was banned in India and in several Muslim states; it caused violent protests in Islamabad and provoked the public burning of the book by a Muslim community in Bradford. Ayatollah Khomeini issued the fatwa against Rushdie and since then Rushdie has been in hiding. After 'Shame' he turned to the western world with his novels 'The Moor's Last Sigh' (1995) and 'The Ground beneath her Feet' (1999) and a collection of short stories 'East- West' (1994) where the Western and the Eastern worlds meet. He has also written a children book Haroun and the Sea of Stories (1990) and some essays and critical works collected in Imaginary Homelands: Essays and Criticism, 1981-1991 (1992). In his work- 'Shalimar, the Clown' (2005), he again returns to India and Pakistan and deals with the topics of India's independence, the partition of India and Pakistan and the war between the two countries.Rushdie's latest novel 'Two years, eight months, and twenty- eight nights,', highly anticipated as it comes seven years after his last novel 'The Enchantress of Florence', and three years after his brilliant memoir 'Josef Anton', where the prose is electric, the descriptions dazzling in their word play, the, strangeness, is multiple and the, guess- who-game, as intriguing as ever. Several critics (e.g. Hilský, Seminck) of his work describe his writing method as Magical realism. He is also a representative of the phenomena called the postcolonial writing described in The Empire Writes Back by Bill Ashcroft, Gareth Griffiths and by Helen Tiffin.

Midnight's Children is regarded as a postcolonial text and if postcolonial literature is understood in the binary model of colonizer vs. colonized, then Rushdie's narrative fits in that model. Since postcolonialism remains part of English Studies, critics who focus on colonialism also endorse the view of Rushdie as a perfect postcolonial writer. Protagonists or narrators in postcolonial writings are often found to be pressed with the questions of identity, conflicts of living between two worlds and the forces of new cultures. Postcolonial writings take place through the process of re-writing and rereading the past. 'Midnight's Children' recounts the history of India's transition from British colonialism to independence. The story is expressed through various characters endowed with magical powers and is located within history. The novel is an allegory of India before and after the independence and partition of India which took place at midnight of August 15, 1947. The narrator of the story is Saleem Sinai with an enormous nose and other magical powers like telepathy.

Rushdie wants his 'Midnight's Children' to question the colonial paradigms so that the constructed, others, may give India and some such colonized countries a decolonized identity. The opening sentence in the novel reads like this: Saleem tells, "I was born in the city of Bombay...once upon a time."(p3)The initial part of the statement gives a picture of social realism during the time of 19th century and the later part reflects the traditional fairy tale to indicate the forthcoming fantasy. Saleem is in need of these two techniques to achieve his purpose of creating a significant identity in an anarchic world. Rushdie's view of the -unchanging two-ness of things, the duality of up against down, and good against evil- finds parallel in the term magical realism. The search for the whole in Saleem can be acknowledged as finding what will make up his identity which is a central concern in postcolonialism. We are able to understand that the author is trying to make us understand that his subject is identity, both national and personal. Saleem's magical realist physical fracturing is also a critique of the colonial predicament of identity fragmentation which results from the contamination of 
foreign culture in the native's corpus. As we have already seen, Saleem continuously links his life to that of the country. Saleem tries to understand his country's colonial past, makes sense out of its.

\section{CONCLUSION}

That's how the novels of both Amitav Ghosh and Salman Rushdie explore the ways in which history is given meaning through the retelling of individual experience.Post-colonialism is seen through history of subjectively through the eyes of the protagonists Rajkumar and Saleem Sinai, therefore the retelling of history is fragmented and, at times, erroneous. Amitav Ghosh's The Glass Palace and Rushdie are relating of Rajkumar and Saleem's generation of both in The Glass Palace and 'Midnight's children' to the generation of Indians with whom he was born and raised. As a product of postcolonial India, Rajkumar and Saleem piece together the multifarious fragments of their identity, just as India begins a new in rebuilding her identity in the wake of colonialism. Rajkumar and Saleem's stories represent the plural identities of India and the fragmented search for self through memory.

Language is one of the tools of decolonization both Amitav Ghosh and Rushdie who are the master of exercising this device. They both take the words of Hindi, Urdu and other regional languages and English sizes them without any reference or notes. They demonstrate the complexities and dilemmas that the project of Indian is the resources of English language entails. In each of their novel they inter mingles words from several origins and tries to make them perfect, Such as, Dunia, Duniazat, D’Niza, and Mr. Airagaira. Thus, they become the leaders of postcolonial authors who have taken the oath of provincial zing English, who are determined to subvert the master's tool in order to make it as their own.

It is interesting to look into how the diasporic writers both Amitav Ghosh and Salman Rushdie did a work of "magic" with languages in order to find their own voice to tell their un rooted and hybrid stories. Hybridity and un rootedness are essential aspects of their writing. This traces Amitav Ghosh and Rushdie's experiments with languages from The Circle of Reason to Midnight's children, the novels where they felt, they found a voice of their own, and from The Enchantress of Florence, the novels of linguistic and artistic refinement, and through the beguiling and astonishing -Two Years, Eight Months and Twenty-Eight Nights, - and The Glass Palace are the novels that are not steeped in the magical world of thunderbolt- releasing mortals and endlessly copulating Gods?. From one novel to the next, Ghosh and Rushdie found new inflections of their voice through their narrators and Within these three connected themes, the novels explored the problems of Postcoloniality, depicted in these novels as the difficulties in assigning one's point of personal or national origin, the problems in determining one's personal and national history characters, which chutnified English, translated their languages into their idioms, aestheticized their world, disoriented it, turned it into a hypertext, or seduced the readers with their stories.

\section{REFERENCES}

\section{Books, Articles and Reviews}

Adhikari, Madhumalati. 'The Calcutta Chromosome: A post-Colonial_Novel' in Indira Bhatt and Indira Nityanandam (eds.) The Fiction of Amitav Ghosh: 177-83. Print.

Almond, Ian. 'Post-Colonial Melancholy: An Examination of Sadness in Amitav Ghosh's The Shadow Lines'. Orbis Litterarum. 59.2 (2004): 99-99. Print.

Anderson, Benedict. Imagined Communities: Reflections on the Origins and Spread of Nationalism. London: Verso. 1983. Print.

Ashcroft, Bill, Gareth Griffiths and Helen Tiffin's The Empire Writes- Back 1989, eds. Key concepts in Post-Colonian. Routledge 1998. Print.

Barry, Peter. Biginning Theory: An introduction to literary and Cultural theory. Manchester and New York: Manchester University Press. 1995. Print.

Benita, Parry. Problems in Current Theories of Colonial- theories. Oxford Literatury review of 1987. Print.

Bhabha, Homi. K. Nation and Narration and The location of culture. New York: Routledge. 1990, 1994. 5 March 2010. Print. 
Boehemer, Ellike. Colonial and Postcolonial literature: My grant Metaphores. Londaon: Oxford Press, 1995. Print.

'Footnoting History: The Diasporic Imagination of Amitav Ghosh' in Makarand Paranjape (ed) In Diaspora: 235-45.

Budhos, Marina. 'Questions of Allegiance:Review of The Glass Palace'. Los Angeles Times Book Review.(11February 2001): 5. Print.

Chakravorty, Gayatri Spivak. In Other Worlds: Essays in Cultural Politics. London: Routledge, 1988. Print.

Chambers, Claire. The Relationship between Knowledge and Power in the Work of Amitav Ghosh Leeds, 2003. Print.

Champeon, Kenneth. 'The Last Queen of Burma'. The Iriwaddy. I July < http://www.irrawaddy.org. > 2003. Print.

Chatterjee, P. The National and its Fragments: Colonial and Post- Colonial histories. Princeton: Princeton University Press 1993. Print. 'Nationalist thought and colonial world: London Press 1986. Print.

Dayal, Samir. 'The Emergence of the Fragile Subject: Amitav Ghosh's In an Antique Land' in Monika Fludernik (ed.) Hybridity and Postcolonialism. ZAA Studies: Language, Literature, and Culture. I. Tubingen, Germany: Staufenburg, 1998.8: 103-33. Print.

Dutta, P.K. "Thematic and Structural Concerns" on Ghosh's The Glass Palace. 1990: 67. Print.

Fanon, Frantz's Black Skin White Masks (1952) and Wretched of the Earth. Scottish Academic Press, 1967. Print.

'Footnoting History; The Diasporic Imagination of Amitav Ghosh' in Markar and Paranjape(ed) In Diaspora: 235-45.

Ganguly, Keya. 'Something Like a Snake: Pedagogy and Postcolonial- Literature'. College Literature.19-20.3-1(1992 Oct-1993

Feb): 185-90. Print.

Gellner, Ernest. In Nations and Nationalism London Press: 1983. Print.

Hussain, Shawkar. 'Post-Colonial Angst in Amitav Ghosh's The Shadow Lines' in Niaz Zaman et al (eds.) Colonial and Post-Colonial Encounters Dhaka:Manohar Publications, 1999. Print.

Mc Leod, John. Beginning Post-Colonialism: Manchester: Manachester University Press 2000. Print.

Mishra, Pankaj. 'Review of The Glass Palace'. New York Times Book Review 106.6 (2001):7. Print.

Mongia, Padmini. 'Medieval Travel in Postcolonial Tmies: Amitav Ghosh's In Antique Land' in Tabish Khair (ed.) AmitavGhosh: 73-89.

Morkal, Rakhee. "In Time of Breaking of Nations'. The Glass Palace as Postcolonial Narrative" in Brinda Bose (ed.) Amitav Ghosh: 139-54.

'In Antique Lands, ' Indian Review of Books, 7:10 (1998): 6-8. Print.

'Dancing in Cambodia, At Large in Burma'. India Star Reviewof Books. 1998. http://www.indiastar. com/mukherjee1.html

Mukherjee, M.. 'Of Love, War and Peace,' review of The GlassPalace, Indian Review of books, Vol. 10, No.1. 2000. Print.

Nair, Rukmini Bhaya. 'The Road from Mandalay: Reflections on Amitav Ghosh's The Glass Palace' in Tabish Khair (ed.) Amitav Ghosh: 162-74.

Pandit, Nirzari. 'Subversion of History in/ through Fiction: A Study ofThe Shadow Lines and In an Antique Land' in Indira Bhatt and Indira Nityanandam (eds.) The Fiction of Amitav Ghosh: 13341.

Peterson, Kirsten Holst. And Anna Rutherford: 'Double colonization' in A Double Colonization, Colonial and Post-Colonial Women's Writing. 1986. Print.

Premnath, Gautam. 'Arguments with Nationalism in the Fiction of the Indian Diaspora'. Diss., Brown University, 2003. Print.

Rakhee, Moral. 'The Postcolonial Writing on The Glass Palace' 2003: 151-152. Print. 
Understanding the Post-Colonial Literature in the Novels of Amitav Ghosh and Salman Rushdie- A Postcolonial Comparative Study

Ravi, P.S. Modern Indian Fiction: History, Politics and Individual in the Novels of salman Rushdie, Amitav Ghosh and Upamanyu Chatterjee New Delhi: Prestige Books, 2003. Print.

'Ray Satyajit' in Tabish Khair (ed.) Amitav Ghosh: A Critical - Companion New Delhi: Permanent Black, 2003: 108. Print

Shammas, Anton. 'The Once and Future Egypt: Review of In An Antique Land'. New York Times Book Review. (1 August 1993). Sec.VII. 26. Print.

Sircar, Arjya. 'The Stranger Within: Amitav Ghosh's Quest for Identity'. Language Forum. 18.1-2 (1992): 143-47. Print.

Skinner, John. 'Embodying voices: Language and Representationin Amitav Ghosh's The Glass Palace'. BELL: Beligian Essay. On Language and Literature (2002): 137-49. Print.

Soueif, Ahdaf. 'Intimately Egyptian: Review of In An Antique Land'. Times Literary Supplement. (15 January 1993): 7. Print.

Srivastava, Neelam. 'Amitav Ghosh's Ethnographic Fictions: Intertextual Links between In an Antique Land and His Doctoral Thesis'. Journal lof Commonwealth Litrature. 36.2 (2001): 4564. Print.

Stageman, Mike. 'Innocence Lost: Indo-Anglian Representations of Post-Colonial Identies Through Adoliscent Hardships'. Diss, 2001. Print.

Tadie, A. 'Amitav Ghosh: The Nuances of History'. Esprit (Paris)1 (2002): 62-73. Print.

'The Novels of Amitav Ghosh'. London Magazine. 37.3-4 (1997): 159-61.

'The Politics of Isolation and Resurgence in Dancing in Cambodia, at Large in Burma' in R.K.Dhawan (ed.) The Novels of Amitav Ghosh: 282-94.

Thieme, J. 'The Discoverer Discovered: Amitav Ghosh's The Glass Palace,' in The Literature of Indian Diaspora: Essays in Criticism, ed by A.L. M.cLeod, New Delhi: Sterling Publishers, 2000. Print.

Tiwari, Shubha. Amitav Ghosh: A Cirtical Study New Delhi: Atlantic Publishers, 2003. Print.

'Travelling in the West: The Writing of Amitav Ghosh' in Tabish khair (ed.) Amitav Ghosh: A Critical Companion Delhi: Permanent Black, 2003: 9-35.Print.

Trikha, Pradeep. 'In An Antique Land: A Traveller's Tale' in R.K.Dhawan (ed.) The Novels of Amitav Ghosh. New Delhi: Prestige, 1999: 187-91.Print.

Tripathi, salil. 'The Past is Now: Review of Dancing in Cambodia, At Large in Barma'. Far Eastern Economic Review. 61.31 (30 July 1998): 42-43. Print.

Vinoda. T "Reflections on the Crystal Palace: The Glass Palace as a Post Colonialist Text". Kakatiya Journal of English Studies. Volume 22. . 2002. Print.

Wassef, Hind. 'Beyond the Divide: History and National Boundaries in the Work of Amitav Ghosh'. Alif: Journal of Comparative Poetics. 18 (1998): 75-95. Print.

Weisbord, Merrily. 'Amitav Ghosh; College English Review' 1.4 (1997): 4-5. Print.

Young, Robert J.C. Postcolonialism: A Very Short Introduction New York: Oxford UP, 2003. Print.

Zinkin, Taya. 'Review of Dancing in Cambodia, At Large in Burma'. Asian Affairs. 30.2 (1999): 23031. Print. 


\section{AUTHORS' BIOGRAPHY}

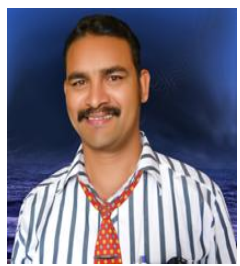

Dr.Venkateswarlu Yesapogu awarded his $\mathrm{PhD}$ degree in (2012) in the contemporary Indian fiction at the Acharya Nagarjuna University, GUNTUR, Andhra Pradesh, India, his M.A., M.Phil, also happened in the English literature. $\mathrm{He}$ is now teaching English Literature and Phonetics in V.V. \&M. Degree College ONGOLE. He became the youngest Principal FAC by virtue of awarded $\mathrm{PhD}$ and sexity among existing staff since 2009 . His teaching is on main research interests including teaching of Phonetic Science as well as communication skills. He has recently published two books. The first entitled "The Fictional World of Amitav Ghosh" with ISBN 9789382186397; and published several other articles in reputed international journals. He has participated National and International seminars/conferences.

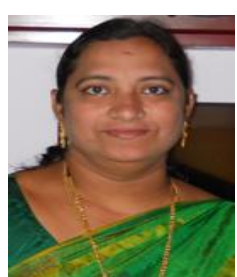

Smt. Manjula Kandula who is the present Principal of Priyanka college of Education, Chekoorapadu, Cheerala road, ONGOLE, PRAKASAM D.T. A.P. INDIA. She did her M.A. Litt, in English Literature. And also she completed M.Ed in Education in Acharya Nagarjuna University Guntur A.P. India. Moreover, She also awarded her M.Phil in Education from M.K.University, Madurai, T.N. India. Right now she is also working as an Assistant Proferssor in A.N.U. P.G. Centre Campus, ONGOLE, Prakasam D.T., A.P., India, as a guest faculty. 